\title{
Evaluating the effectiveness of integrated Accounting Information Systems (AIS) in ERP environment of Vietnamese garment companies
}

\author{
Vu Quoc Thong ${ }^{1 *}$ \\ ${ }^{1}$ Ho Chi Minh City Open University, Vietnam \\ *Corresponding author: thongvu99@gmail.com
}

\begin{tabular}{|c|c|}
\hline ARTICLE INFO & ABSTRACT \\
\hline $\begin{array}{l}\text { DOI: } 10.46223 / \mathrm{HCMCOUJS} \text {. } \\
\text { econ.en.9.1.174.2019 }\end{array}$ & $\begin{array}{l}\text { Identifying factors defining the effectiveness of integrated } \\
\text { AIS in the Enterprise Resource Planning (ERP) environment is } \\
\text { really a challenging task. In our research, the effectiveness of } \\
\text { integrated AIS in ERP is presented in the form of a Balanced } \\
\text { Scorecard (BSC) model. This study analyzes data collected from }\end{array}$ \\
\hline Received: November $3^{\text {rd }}, 2018$ & 178 Vietnamese garment companies with AIS in an ERP \\
\hline Revised: January $17^{\text {th }}, 2019$ & environment. Then, Cronbach's Alpha test and exploratory \\
\hline Accepted: March $4^{\text {th }}, 2019$ & $\begin{array}{l}\text { factor analysis (EFA) are conducted to assess the reliability of } \\
\text { variables. The result identifies } 28 \text { variables from Vietnamese } \\
\text { garment companies' managers view grouped into 4-dimensional } \\
\text { constructs of the BSC model that define the effectiveness of } \\
\text { integrated AIS in an ERP environment. The conclusion on }\end{array}$ \\
\hline $\begin{array}{l}\text { AIS effe } \\
\text { garment, }\end{array}$ & $\begin{array}{l}\text { garment companies' AIS evaluation factors paves the way for } \\
\text { future research on other Vietnamese industries' AIS evaluation } \\
\text { in an ERP environment. }\end{array}$ \\
\hline
\end{tabular}

\section{Introduction}

While the global business environment is more dynamic and complex, the level of competition among companies is becoming fiercer (Chanopas, Krairit, \& Khang, 2006). Garment companies in Vietnam are not an exception. In the national development plan for the period between 2020 and 2030, the garment and textile sector is classified as a key sector in Vietnam (VIRAC Vietnam, 2018). Garment companies are currently facing various problems including difficulties in supporting information for decision-making, unreasonable use of economic resources and limited supply of input materials. The difficulties reduce their competitiveness and the ability of international integration. On the non-financial aspect, information system (IS) in IT 4.0 environment is considered a tool to assist in improving the competitiveness of garment companies (S. M. Huang, Lee, \& Kao, 2006; Lee, Kao, \& Yang, 2014). Unlike the 1990s, companies became more cautious in investing in IS and started to consider the benefits of ISs to their business goals during the 2000s (Carr, 2003). The benefits of these ISs cannot be adequately estimated because they cannot be measured in terms of qualitative and non-financial values generated by such information systems (Farbey, Land, \& Targett, 1992). In the context of an integrated information system - the ERP system application for large garment companies, it is necessary to conduct the effectiveness evaluation of integrated AIS in an ERP environment. The AIS effectiveness is one of the indicators for the 
added value that the information system contributes to an organization by helping the organization achieves its goals (Greenspan, 2000; Santhanam \& Hartono, 2003). Obtaining the evaluation result of AIS effectiveness helps to push the integrated AIS in ERP environment implementation by Vietnamese garment companies' managers.

This article constructs the model for evaluating the effectiveness of integrated AIS in ERP environment based on the Balanced Scorecard (BSC) theory. By 2010, no research in Vietnam has applied the BSC theory to develop a model for evaluating the effectiveness of integrated AIS in an ERP environment among Vietnamese garment companies. This paper has two objectives:

1) Evaluate the effectiveness of integrated AIS in an ERP environment among Vietnamese garment companies; and

2) Identify factors defining the effectiveness of integrated AIS in an ERP environment of Vietnamese garment companies.

The remainder of this paper is organized into four sections. First, the literature review section looks at prior research that informs this study. Next, methodology section shows the research model and measurement design. Then, the third section presents the research findings. Finally, there will be conclusions and some recommendations for future studies.

\section{Literature review}

\subsection{International research}

The convergence of financial and management accounting in the computer-based accounting environment is a striking finding discussed by Taipaleenmäki and Ikäheimo (2013). This disclosure has appealed much attention from researchers interested in AIS under the influence of Information Technology (IT). With the increasing impact of technology, the boundaries between technology and empirical behaviors from financial accounting and management accounting could be blurred when assessing the effectiveness of the entire AIS at the organizational level. Gimžauskienè \& Klovienè (2014) continued to announce the impact of IT in the post-2010 period on the relevance of AIS and the business environment. In their research, they used qualitative methods to investigate the influences of AIS development from the business environment in the context of IT's assistance. Coyne, Coyne, and Walker (2017) published some skills needed by accountants to be able to handle the ERP-accounting system. The result suggested that accountants should be on the standpoint of the managers to control and exploit accounting data from the ERP environment. One of the reasons cited by Coyne et al. (2017) was that users could pay more attention to exploit strategic accounting data if they have the same viewpoints with the management board. These recently updated research helps the author recognize that the assessment of the effectiveness of integrated AIS in the ERP environment should be carried out at the entire company level and from the perspective of its managers.

Presently, the measurement of IT impacts on the performance of enterprises should be considered in financial and non-financial aspects (Petter, DeLone, \& McLean, 2012). This paper, therefore, focuses on evaluating the effectiveness of integrated AIS in an ERP environment under the BSC model from the perspective of Vietnamese garment companies' managers. 
The BSC theory was introduced by Kaplan and Norton (1992) with 4 theoretical constructs comprising of finance, customer, business process and learn and growth (Figure 1).

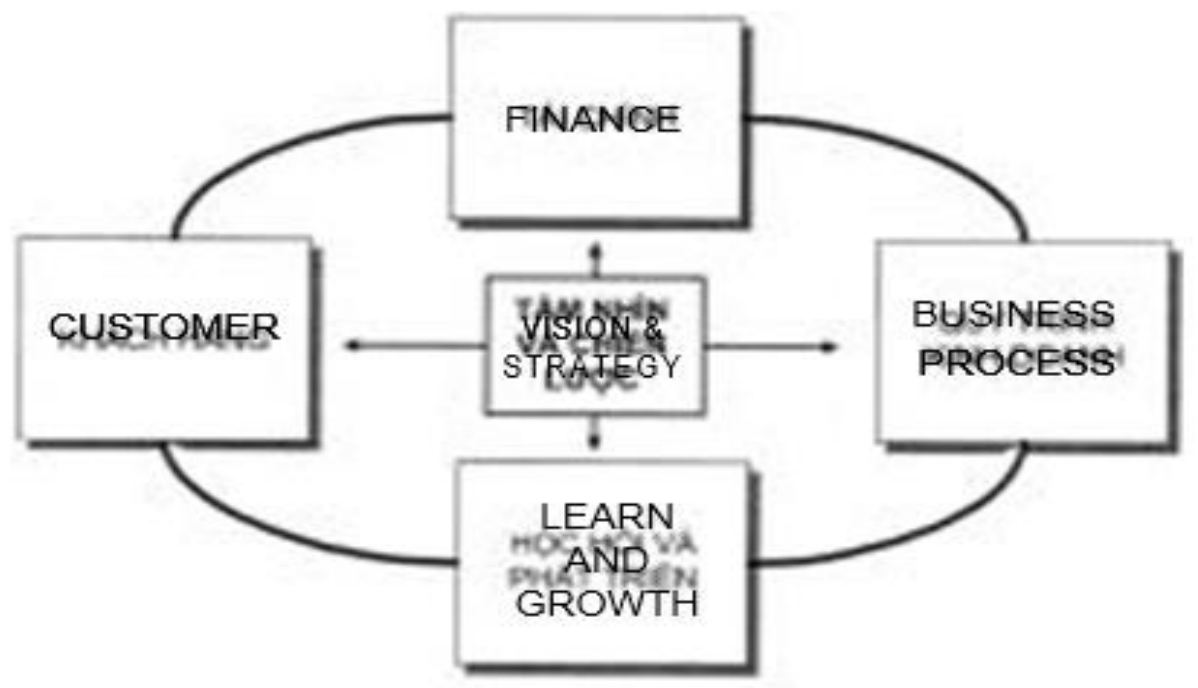

Figure 1. Balanced Score Card (BSC) theoretical model

BSC theory forms a foundation for building a measurement scale for a good deal of managerial research targeting on business performance. The IS value depends on how IS assists enterprises in achieving their business objectives and implementing their business strategies (Luftman \& Brier, 1999). Many IS researchers have applied the BSC model to investigate the impact of IS on business organizations.

Researchers across the globe have conducted several studies on the application of the BSC model to measure the effectiveness of information systems. Grembergen and Haes (2005) proposed specific criteria for the dimensions of the BSC model to measure the effectiveness of Information Systems. Grembergen and Haes' (ibid.) proposal indicated the financial dimension with criteria for increasing business profits, soaring return on equity, growing sales revenue, reducing operating costs and so on. Whilst the non-financial dimension of this model were delivery support, customer-interacting assistance included in customer dimension, or the norms for production capacity boost, working-process restructuring, support for cooperating with the suppliers for business-process dimension, listed as some examples. Some countries employed BSC models to evaluate the information system. For example, Thailand used the BSC model to assess information systems in Thai garment companies (Suanmali, Karabay, \& Kurumer, 2011). Morocco also adopted BSC's criteria to evaluate information system effecting on the performance of textile firms (Chriyha, Beidouri, \& Bouksour, 2012). Italy used the BSC model to assess the effectiveness of decision support systems in fashion companies (Felice \& Petrillo, 2013). For Pakistani garment companies, Maqbool (2015) utilized the four-dimension BSC model to propose an additional supply chain dimension to appraise the impact of an information system on the entire company. Maqbool recommends that the application of the BSC model in assessing the effectiveness of the system should be widely validated in other industries of various countries (Maqbool, 2015). 


\subsection{Domestic research}

Up to 2010, there has been no research on the application of the BSC-theory model for evaluating the effectiveness of information systems on Vietnamese economic organizations at the company level.

However, there are some interesting facts relating to this issue. There were some workshops held in Vietnam introducing and discussing the application of BSC for corporate management in 2005. Since then, some Vietnamese consulting firms such as Vietnam Marketing and Management Institute, BSC consultancy company - Toppion and so on discovered the potential for applying BSC in the company's evaluation system. Therefore, they invested in implementing training and consulting activities using the BSC model. Some Vietnamese companies such as Phu Thai Group, FPT Corporation and Kinh Do Mondelez Company have started applying the BSC model. However, initial survey results showed that the application of the BSC model for assessing ISs was still vague and unpopular in Vietnamese garment companies. Based on the practical factors, the author acknowledges that the assessment of a business's AIS by the BSC model has some limitations. A good deal of relevant research is in the themes of organizing, improving and proposing solutions to enhance the use of accounting software for companies. These include research done by Dao (2002), Tran (2007), D. H. Nguyen (2011), H. D. Nguyen (2012) and a recent study on AIS in the ERP environment conducted by B. L. Nguyen (2013). Most of the previous research has not been specialized in the field of evaluating AIS; particularly, no BSC model has been applied for evaluating AIS in a specific industry yet.

After reviewing international and local studies on the issue, we feel the need for researching on an evaluation of Information System effectiveness in specific ERP-AIS context. This study, therefore, presents the BSC-based model and the results of new factors defining the effectiveness of integrated AIS in an ERP environment in Vietnamese garment companies.

\section{Research methodology}

Many researchers have proposed guidelines for building a research model including a measurement scale for the model (Churchill, 1979; Dunn, Seaker, \& Waller, 1994; MacKenzie, Podsakoff, \& Jarvis, 2005). Referring to previous guidelines; the author defines step-by-step directions to implement this research (Table 1).

\section{Table 1}

Research direction summary

\begin{tabular}{|l|l|}
\hline $\begin{array}{l}\text { Step 1. AIS evaluation in the garment } \\
\text { companies }\end{array}$ & $\begin{array}{l}\text { Synthesizing studies in relevant to AIS assessment in } \\
\text { companies around the world and in Vietnam; mainly } \\
\text { garment companies. }\end{array}$ \\
\hline $\begin{array}{l}\text { Step 2. Research model and observed } \\
\text { variables }\end{array}$ & $\begin{array}{l}\text { Cementing the research model based on the BSC } \\
\text { theory in assessing AIS in an ERP environment } \\
\text { for garment companies. } \\
\text { Notice: Select measurement criteria under the } \\
\text { dimensions of the BSC model from previous studies. }\end{array}$ \\
\hline
\end{tabular}




\begin{tabular}{|l|l|}
\hline Step 3. Conduct an in-depth interview & $\begin{array}{l}\text { Conducting in-depth inquiry with some ERP-AIS } \\
\text { experts to develop the survey: assessing the } \\
\text { effectiveness of AIS in an ERP environment. }\end{array}$ \\
\hline Step 4. Conduct a pilot test & Reviewing the questionnaire constructed on the small \\
sample and completing the whole questionnaire.
\end{tabular}

Source: The researcher's data analysis

The following subsections present in detail the step-by-step implementation of this research.

\subsection{AIS evaluation in garment companies}

Business managers desire to measure the effectiveness of the organization in achieving the goals set by the company. For example, Palvia, Perkins, and Zeltmann (1992) studied the impact of strategic information systems on the effectiveness of the organization - the Federal Express Corporation.

A survey conducted by Silk (1998) in the United States reported that up to $60 \%$ of US companies performed an evaluation of the effectiveness of the information system through the following criteria: quality of information, satisfaction from the users and use of the system. Hoque and Wendy (2000) studied the influence of a company's size on the assessment of information systems supporting decision-making. Factors such as total revenue, total assets and the number of employees represent the size of business. Larger-scale companies tend to implement assessment of information systems clearly. In New Zealand, Blundell, Sayers, and Shanahan (2003) carried out a survey on 40 large-scale companies to discover how they evaluated the efficiency of computer-based accounting systems. The study applied finance and 
learn and growth criteria to evaluate the effectiveness of the computer-based accounting system. In the garment field, the evaluation of information system was conducted to assess the supply chain management system of Thailand garment companies (Suanmali et al., 2011), evaluate how information systems affect the performance of Morocco garment companies (Chriyha et al., 2012) and measure the effectiveness of decision support systems for Italian fashion companies (Felice \& Petrillo, 2013). Besides, another study also assessed the impact of comprehensive information systems in Pakistan garment companies (Maqbool, 2015).

So far, there has been no consensus in measuring the effectiveness of ISs at the organizational level in a specific industry like a garment. The choice of scales for this concept in previous research lacks of judgment from a theoretical foundation. Financial and accounting scales were widely applied to reflect the performance of an organization. However, the financial scale was not the sole measure due to the complex nature of the effectiveness of information systems in the ERP environment. The use of a financial scale could merely result in the inadequacy of the research model's conclusion (Hitt, 1988). The effectiveness of AIS at the organizational level is at stake if being separated from the ERP environment. The proposal for applying the BSC model to measure the effectiveness of information systems in the ERP environment has been published in studies by Grembergen and Haes (2005), and Grembergen and Haes (2017). For the garment industry, the application of the BSC model for evaluating information systems has been initially applied in the world. In this article, the author proposes the BSC model to assess the effectiveness of AIS in an ERP environment in the Vietnamese context.

The next section presents how we identify observed variables for measurement constructs.

\subsection{Research model and observed variables}

Based on results from previous research, we believe that to fully evaluate the effectiveness of integrated AIS in an ERP environment; we need to build a model with both financial and non-financial factors (Grembergen \& Haes, 2005; Hitt, 1988). In this paper, we propose the research model using BSC approach. 


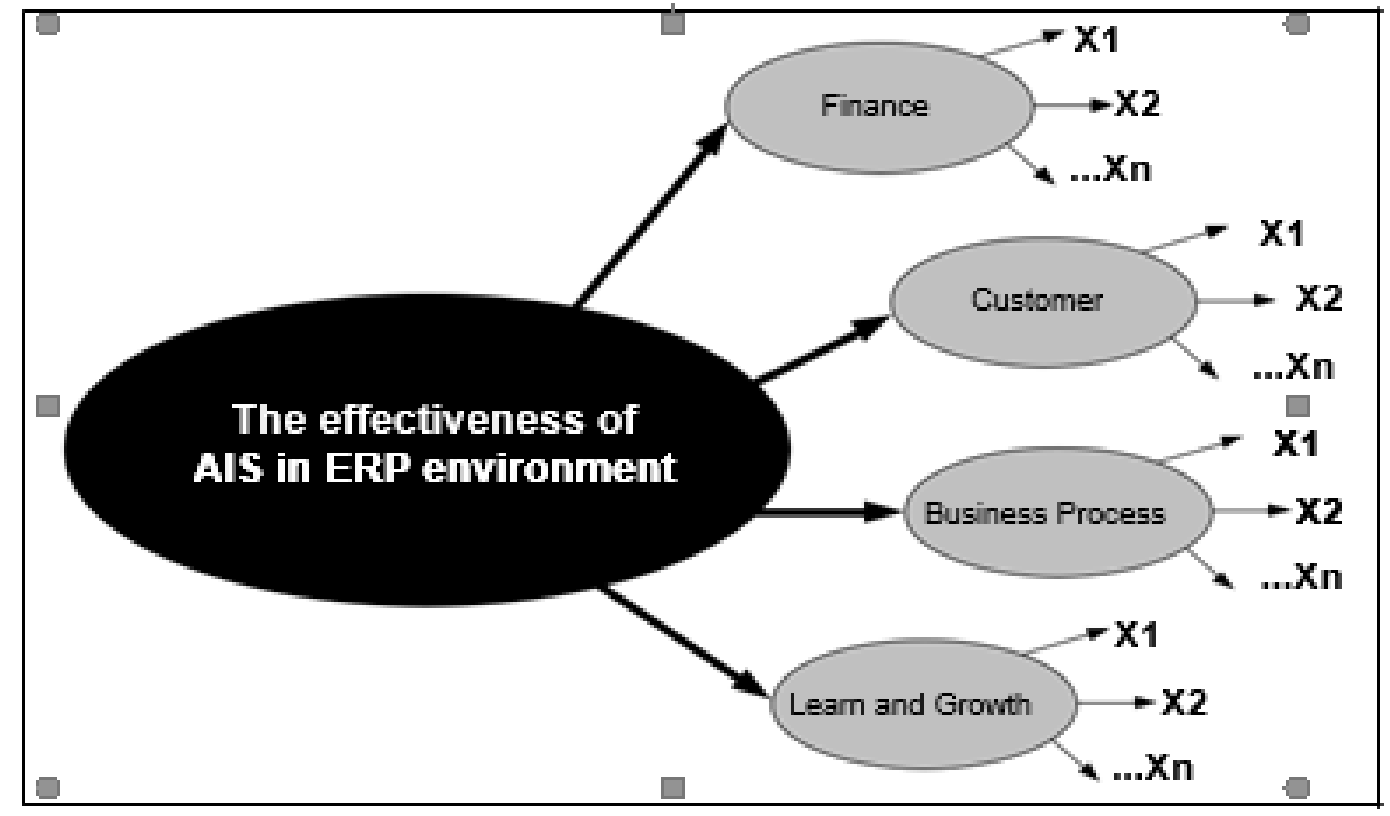

Figure 2. Proposed research model

The research model illustrates the main measured concept - The effectiveness of AIS in ERP environment - which is a second-order construct defined by 4 first-order constructs including finance, customer, business process and learn and growth (Figure 2). Although the second-order construct is a multi-dimensional construct, the observed variables of each firstorder construct need to be uni-dimensional.

Observational factors in finance construct used in past studies are in different forms. Bryant, Jones, and Widener (2004) proposed a group of financial factors for evaluating organizational performance including the increases in revenue and return on investment. As proposed by Bhagwat and Sharma (2007), financial ratios include Return on cash flow, Revenue increase, Return on equity (ROE), Return on Sale (ROS), Return on Asset (ROA) and so on. In addition, ratios such as revenue to cost, number of e-transactions in total revenue, expansion of market share, employee redundancy and deduction in cost of wages are also added to the financial measures by L. Huang (2008).

The studies used some factors to determine customer construct including improvement in customer service and accuracy in order delivery (Velcu, 2007). Market share, customer retention, and customer satisfaction are found in studies by Chia, Goh, and Hum (2009) when identifying the definition of customer concept. Customer concept is also defined by capacities for obtaining contracts, market share, customer satisfaction, and corporate reputation in providing quality services (Chen \& Mohamed, 2008). Applying integrated AIS is one of the great ways to achieve customer goals.

There are several determinants of business process construct found in past studies. For example, flexibility in delivery, responsiveness to emergency orders, accuracy in forecasting, and timely delivery of new products (Park, Lee, \& Yoo, 2005). Throughout the business process, time is regulated for accounting tasks, access to information and process management (Velcu, 2007). In addition, L. Huang (2008) also introduced measure factors such as transaction processing means, transaction processing procedures, order processing quality, problem- 
solving, production capacity improvement, better provision of production management, product quality improvement, facilitation of e-commerce development, etc. Chia et al. (2009) study identified factors to measure business process concept including working process restriction, improvement of decision making, quality of service, support in working with suppliers, supporting good control, timely delivery and reduction of operating costs.

Although the determinants of learning and growth construct are less commonly recognized, the author also notes several measuring factors from past studies. For example, L. Huang (2008) suggested group coordination factors-coordination in working among departments and facilitating good coordination among businesses, which motivates employees to work with responsibility and participate in managing and improving self-capacity. In addition, other found determinants include employee satisfaction, productivity, staff skills, etc. (Chen \& Mohamed, 2008), employee satisfaction, job change, and staff training (Chia et al., 2009).

\subsection{Conduct an in-depth interview}

We review articles, case-study in garment companies context to collect relevant observed variables for the first-order constructs in the research model. After data collection, we obtain the list of 65 related variables. According to Churchill (1979), the list of variables needs to be sorted by discussing with ERP-AIS experts to check the content of variables and group them into a suitable measurement construct. There are 6 ERP-AIS experts invited to assist us in reviewing the variable list and put them into a suitable construct. The variables should meet at least 3 expert expectations. This results in a shortlist of 27 variables. The experts also suggest an additions list of variables to measure each construct. Then, similar-meaning variables suggested by at least 3 experts are selected to make 14 extra variables. After that, we work with ERP-AIS experts in modifying descriptions for each observed variable to improve clarification (Table 2).

\section{Table 2}

Variables list after conducting item purification

\begin{tabular}{|l|c|}
\hline \multicolumn{1}{|c|}{ Research construct } & Number of observed variables \\
\hline Finance (FINx) & 9 variables \\
\hline Customer (CUSx) & 7 variables \\
\hline Business Process (BUSx) & 14 variables \\
\hline Learn and Growth (LEAx) & 11 variables \\
\hline
\end{tabular}

Source: The researcher's data analysis

The objective of conducting intensive interviews with AIS-ERP experts is to develop a survey assessing the effectiveness of the integrated AIS in an ERP environment.

\subsection{Conduct a pilot test}

After conducting item purification, a draft version of the survey was sent to 27 garment companies' managers which have implemented integrated AIS in an ERP environment. After collecting data in the pilot test, we perform Explore Factor Analysis (EFA) to verify variables 
for each research construct (D. T. Nguyen, 2013). Using EFA with Principles Components Analysis to evaluate measurement scale, we first ensure the scale items satisfy Bartlett's test of sphericity with $\mathrm{p}$ ratio $<5 \%$ and KMO checking with KMO indicator $>0.5$. Then, we follow the criteria to delete scale items for items loaded $<0.5$ or item loaded $>0.5$ (Hair, Black, Babin, Anderson, \& Tatham, 2005).

In summary, there are 33 variables presented in the form of questions in the final survey (Table 3). The final survey is proven by the content validity and measurement reliability.

\section{Table 3}

Variables list after conducting the pilot test

\begin{tabular}{|l|c|}
\hline \multicolumn{1}{|c|}{ Research construct } & Number of observed variables \\
\hline Finance (FINx) & 9 variables \\
\hline Customer (CUSx) & 6 variables \\
\hline Business Process (BUSx) & 11 variables \\
\hline Learn and Growth (LEAx) & 7 variables \\
\hline
\end{tabular}

Source: The researcher's data analysis

\subsection{Implement mass survey}

Once completing the final questionnaire survey, we conduct quantitative research with a mass survey distribution to 178 Vietnamese garment companies implemented integrated AIS in an ERP environment. The garment companies' managers are the target of survey respondents comprising of CEOs, CFOs, chief accountants, department managers, etc. The data collection process lasts 2 years from 2017 to 2018. Finally, we collect a sample of 91 valid responding (equivalent to $51 \%$ of sent surveys).

Using the collected data, we analyze processed data to answer the research questions. The research findings are presented in the following section.

\section{Findings}

\subsection{Report on the evaluation status of the effectiveness of integrated AIS in an ERP environment among Vietnamese garment companies}

In past AIS studies, there have been some evaluating the company's AIS in the period of ex-ante and ex-post. However, there is no specific evaluation of the value of integrated AIS in an ERP environment in garment companies in Vietnam. The evaluation of the AIS value is inspired by the question "Does the company carry out the evaluation of the integrated AIS in the ERP environment after implementation?". The results show that only $38 \%$ of companies implemented the evaluation while the rest $62 \%$ did not. In terms of the evaluation of ISs, the results of this paper is similar to those of the study conducted by Sohal and $\mathrm{Ng}$ (1998) (41\% carried out evaluation and 59\% did not). However, the results differed from those reported by Lin and Pervan (2003) (77\% had the evaluation and 23\% didn't) and the study by Seddon, Graeser, and Willcocks (2002) (50\% implemented it and 50\% did not). 
On examining the evaluation of integrated AIS in an ERP environment in garment companies in Vietnam, the author collected data in the period when the company conducted its first evaluation. Results showed that around 38\% carried out the first evaluation after 6 months, approximately $30 \%$ carried out the first evaluation from 6 to 12 months and about $17 \%$ conducted the evaluation in 3 years. In terms of the evaluation of AIS in an ERP environment, this has never been mentioned before in international research.

Sohal and $\mathrm{Ng}$ (1998) also mentioned the frequency of AIS evaluation in companies but they did not specify the number of subsequent evaluations from the first. This paper did the same. However, this study also mentioned the frequency of evaluation conducted by the company after the first and the awareness of the IS's value for the integrated AIS in an ERP environment.

In addition, the evaluation of integrated AIS's value in the ERP environment is also inspired by previous studies of Ballantine, Galliers, and Stray (1996), and Sohal and $\mathrm{Ng}$ (ibid.) on company senior managers and department heads. Due to a more specific context of integrated AIS, the number of managers of financial and accounting departments are different from those in of Sohal and Ng's study with about 72\%; this study get responses from all 91 managers of financial and accounting departments of the garment companies (100\%) evaluating the integrated AIS participated in the survey.

4.2. Factors defining the effectiveness of integrated AIS in ERP environment of Vietnamese garment companies

\subsubsection{Cronbach's Alpha test}

The author evaluates the reliability of the scale by determining Cronbach's Alpha for each research construct: financial, customer, business process and learn and grow.

\section{Assessment on scale reliability for Finance construct (FIN)}

From the results of the scale evaluation, the authors exclude variables with a correlation coefficient < 0.3 (Hackman, Gundergan, Wang, \& Daniel, 2006; Sundin, Hochwälder, \& Bildt, 2008), which are market share expanding variables (with a correlation coefficient of 0.216) and staff reductions (with a correlation coefficient of 0.197). After excluding variables with small-sum coefficient correlates, the author continues to run Cronbach's Alpha again to assess the reliability. The second testing result shows the reliability of the Finance construct scale through the observation variables with the Cronbach's Alpha coefficient of 0.922 (satisfactory) and the correlation coefficient of the observational variables > 0.5 (Table 4).

\section{Table 4}

Cronbach's Alpha $2^{\text {nd }}$ test result - Finance construct

Reliability Statistics

\begin{tabular}{|c|c|}
\hline Cronbach's Alpha & No. of variables \\
\hline 0.922 & 7 \\
\hline
\end{tabular}


Item-Total Statistics

\begin{tabular}{|l|l|c|c|c|}
\hline \multicolumn{2}{|l|}{} & $\begin{array}{c}\text { Scale Mean if } \\
\text { Item deleted } \\
\text { Variance if } \\
\text { Item } \\
\text { deleted }\end{array}$ & $\begin{array}{c}\text { Scale } \\
\text { Item-Total } \\
\text { Correlation }\end{array}$ \\
\hline FIN1 & Increase business profits & 50.4652 & 66.669 & 0.631 \\
\hline FIN2 & Increase Return on Equity (ROE) & 50.5130 & 66.714 & 0.782 \\
\hline FIN3 & Increase sales revenue & 50.3696 & 67.435 & 0.669 \\
\hline FIN4 & Minimize operating costs & 50.3348 & 65.001 & 0.793 \\
\hline FIN5 & Increase Return on Investment (ROI) & 50.2826 & 72.728 & 0.532 \\
\hline FIN6 & Increase Return on Assets (ROA) & 50.5001 & 69.491 & 0.657 \\
\hline FIN7 & Minimize labor costs & 50.2783 & 67.643 & 0.524 \\
\hline
\end{tabular}

Source: Data analysis result of the research

\section{Assessment on scale reliability for Customer construct (CUS)}

With invalid variables of correlation coefficient $<0.3$, all Customer construct variables are considered to be reliable and not be removed. Cronbach's Alpha test results are shown in Table 5.

\section{Table 5}

Cronbach's Alpha test result - Customer construct

Reliability Statistics

\begin{tabular}{|c|c|}
\hline Cronbach's Alpha & No. of variables \\
\hline 0.911 & 6 \\
\hline
\end{tabular}

Item-Total Statistics

\begin{tabular}{|l|l|l|l|l|}
\hline \multicolumn{2}{|c|}{} & $\begin{array}{c}\text { Scale Mean } \\
\text { if Item } \\
\text { deleted }\end{array}$ & $\begin{array}{c}\text { Scale } \\
\text { Variance if } \\
\text { Item deleted }\end{array}$ & $\begin{array}{c}\text { Corrected } \\
\text { Item-Total } \\
\text { Correlation }\end{array}$ \\
\hline CUS1 & Support order delivery & 18.8490 & 1.321 & 0.865 \\
\hline CUS2 & Create better transaction value for customers & 18.8824 & 1.206 & 0.781 \\
\hline CUS3 & Support interactive services with customers & 18.8470 & 1.307 & 0.813 \\
\hline CUS4 & Improve customer satisfaction & 18.7542 & 1.201 & 0.765 \\
\hline CUS5 & Establish relationships with customers & 18.8419 & 1.303 & 0.810 \\
\hline CUS6 & Improve the quality of customer service & 18.6324 & 1.108 & 0.741 \\
\hline
\end{tabular}

Source: Data analysis result of the research 


\section{Assessment on scale reliability for Business Process construct (BUS)}

From the results of the scale evaluation, the authors exclude variables with a sum correlation coefficient of <0.3 (Hackman et al., 2006; Sundin et al., 2008), which are support of the introduction of new products (with a correlation coefficient of 0.118). After excluding variables with small sum correlation coefficient, the author continues to conduct Cronbach's Alpha again to assess the reliability. The second test result demonstrates the reliability of the Business Process construct scale through the observational variables with the Cronbach's Alpha coefficient of 0.901 (Table 6).

Table 6

Cronbach's Alpha 2nd test results - Business Process construct

Reliability Statistics

\begin{tabular}{|c|c|}
\hline Cronbach's Alpha & No. of variables \\
\hline 0.901 & 10 \\
\hline
\end{tabular}

Item-Total Statistics

\begin{tabular}{|l|l|c|c|c|}
\hline \multicolumn{2}{|l|}{} & $\begin{array}{c}\text { Scale Mean if } \\
\text { Item deleted }\end{array}$ & $\begin{array}{c}\text { Scale } \\
\text { Variance if } \\
\text { Item deleted }\end{array}$ & $\begin{array}{c}\text { Corrected } \\
\text { Item-Total } \\
\text { Correlation }\end{array}$ \\
\hline BUS1 & Improve productivity & 28.7088 & 13.157 & 0.626 \\
\hline BUS2 & Restructure the working process & 28.8349 & 12.884 & 0.715 \\
\hline BUS3 & Make changes in the working process & 28.8175 & 13.056 & 0.706 \\
\hline BUS4 & Improve the quality of decision making & 28.8218 & 12.861 & 0.690 \\
\hline BUS5 & Provide better production management & 28.8349 & 12.352 & 0.775 \\
\hline BUS6 & Support for introducing new services & 28.8215 & 13.116 & 0.673 \\
\hline BUS7 & Support inventory management & 28.7301 & 12.650 & 0.708 \\
\hline BUS8 & Improve management productivity & 28.7608 & 12.749 & 0.636 \\
\hline BUS9 & Assist in working with suppliers & 28.7143 & 12.736 & 0.701 \\
\hline BUS10 & Support for better control & 28.8226 & 13.043 & 0.732 \\
\hline
\end{tabular}

Source: Data analysis result of the research

\section{Assessment on scale reliability for Learn and Growth construct (LEA)}

For variables with a total correlation coefficient $<0.3$, the variables under the Learn and Growth construct are creditable and not be eliminated. Cronbach's Alpha test results are shown in Table 7. 


\section{Table 7}

Cronbach's Alpha test result - Learn and Growth construct

Reliability Statistics

\begin{tabular}{|c|c|}
\hline Cronbach's Alpha & No. of variables \\
\hline 0.837 & 7 \\
\hline
\end{tabular}

\begin{tabular}{|l|l|c|c|c|}
\hline \multicolumn{2}{|c|}{ Item-Total Statistics } & $\begin{array}{c}\text { Scale } \\
\text { Scale Mean } \\
\text { if Item } \\
\text { deleted } \\
\text { Variance if } \\
\text { Item } \\
\text { deleted }\end{array}$ & $\begin{array}{c}\text { Corrected } \\
\text { Item-Total } \\
\text { Correlation }\end{array}$ \\
\hline LEA1 & Improve employee motivation & 20.9871 & 8.039 & 0.525 \\
\hline LEA2 & $\begin{array}{l}\text { Allow support services to be shared by all } \\
\text { levels in businesses }\end{array}$ & 20.9740 & 7.764 & 0.636 \\
\hline LEA3 & $\begin{array}{l}\text { Support the development of the business } \\
\text { sector in the market }\end{array}$ & 21.1262 & 7.353 & 0.608 \\
\hline LEA4 & $\begin{array}{l}\text { Encourage staff to actively solve } \\
\text { problems }\end{array}$ & 21.2393 & 7.485 & 0.594 \\
\hline LEA5 & Allow employees to work independently & 21.0436 & 7.658 & 0.592 \\
\hline LEA6 & Support coordination among departments & 21.0656 & 7.021 & 0.702 \\
\hline LEA7 & $\begin{array}{l}\text { Facilitate businesses to work with each } \\
\text { other }\end{array}$ & 20.8754 & 7.913 & 0.624 \\
\hline
\end{tabular}

Source: Data analysis result of the research

\subsubsection{Exploratory Factor Analysis (EFA)}

After Cronbach's Alpha test, 30 observational variables were retained for further analysis of the EFA process. During the first EFA running, Minimize labor costs variable and Support for introducing new services variable presenting small load factors, respectively 0.389 and 0.378, were eliminated. The second EFA analysis outcome shows that the observational variables focused on 4 research constructs with the $\mathrm{KMO}=0.827$, which is satisfactory (Hair et al., 2005) (Table 8). 


\section{Table 8}

Result of the EFA factor analysis

\begin{tabular}{|c|c|c|c|c|c|c|}
\hline \multirow[b]{2}{*}{ No. } & \multirow{2}{*}{\multicolumn{2}{|c|}{ Variables }} & \multicolumn{4}{|c|}{ Research constructs } \\
\hline & & & Finance & Customer & $\begin{array}{l}\text { Business } \\
\text { Process }\end{array}$ & $\begin{array}{c}\text { Learning } \\
\text { and } \\
\text { Growth }\end{array}$ \\
\hline 01 & FIN1 & Increase business profits & 0.833 & & & \\
\hline 02 & FIN2 & Increase Return on Equity (ROE) & 0.812 & & & \\
\hline 03 & FIN3 & Increase sales revenue & 0.775 & & & \\
\hline 04 & FIN4 & Minimize operating costs & 0.754 & & & \\
\hline 05 & FIN5 & Increase Return on Investment (ROI) & 0.747 & & & \\
\hline 06 & FIN6 & Increase Return on Assets (ROA) & 0.722 & & & \\
\hline 07 & CUS1 & Support order delivery & & 0.801 & & \\
\hline 08 & CUS2 & $\begin{array}{l}\text { Create better transaction value for } \\
\text { customers }\end{array}$ & & 0.793 & & \\
\hline 09 & CUS3 & $\begin{array}{l}\text { Support interactive services with } \\
\text { customers }\end{array}$ & & 0.785 & & \\
\hline 10 & CUS4 & Improve customer satisfaction & & 0.742 & & \\
\hline 11 & CUS5 & Establish relationships with customers & & 0.708 & & \\
\hline 12 & CUS6 & Improve the quality of customer service & & 0.694 & & \\
\hline $\begin{array}{l}13 \\
14\end{array}$ & $\begin{array}{l}\text { BUS1 } \\
\text { BUS2 }\end{array}$ & $\begin{array}{l}\text { Improve productivity } \\
\text { Restructure the working process }\end{array}$ & & & $\begin{array}{l}0.812 \\
0.803\end{array}$ & \\
\hline 15 & BUS3 & Make changes in the working process & & & 0.774 & \\
\hline 16 & BUS4 & Improve the quality of decision making & & & 0.762 & \\
\hline 17 & BUS5 & Provide better production management & & & 0.751 & \\
\hline
\end{tabular}




\begin{tabular}{|c|c|c|c|c|c|c|}
\hline \multirow[b]{2}{*}{ No. } & \multirow{2}{*}{\multicolumn{2}{|c|}{ Variables }} & \multicolumn{4}{|c|}{ Research constructs } \\
\hline & & & Finance & Customer & $\begin{array}{l}\text { Business } \\
\text { Process }\end{array}$ & $\begin{array}{c}\text { Learning } \\
\text { and } \\
\text { Growth }\end{array}$ \\
\hline 18 & BUS6 & Support inventory management & & & 0.738 & \\
\hline 19 & BUS7 II & Improve management productivity & & & 0.722 & \\
\hline 20 & BUS8 & Assist in working with suppliers & & & 0.667 & \\
\hline 21 & BUS9 & Support for better control & & & 0.657 & \\
\hline 22 & LEA1 I & Improve employee motivation & & & & 0.802 \\
\hline 23 & LEA2 1 & $\begin{array}{l}\text { Allow support services to be shared by all } \\
\text { levels in businesses }\end{array}$ & & & & 0.797 \\
\hline 24 & LEA3 & $\begin{array}{l}\text { Support the development of the business } \\
\text { sector in the market }\end{array}$ & & & & 0.705 \\
\hline 25 & LEA4 & $\begin{array}{l}\text { Encourage staff to actively solve } \\
\text { problems }\end{array}$ & & & & 0.694 \\
\hline 26 & LEA5 & Allow employees to work independently & & & & 0.656 \\
\hline 27 & LEA6 & Support coordination among departments & & & & 0.649 \\
\hline 28 & LEA7 & $\begin{array}{l}\text { Facilitate businesses to work with each } \\
\text { other }\end{array}$ & & & & 0.573 \\
\hline
\end{tabular}

Rotation: Promax with Kaiser Normalization;

Bartlett test $<0.05$;

General variance deduction: 54.722

Source: Data analysis result of the research

$\mathrm{KMO}$ index $=0.827$

By EFA analysis, the author retains 28 variables grouped by 4 research constructs of the BSC model (Figure 8). These are significant observation variables for evaluating the effectiveness of integrated AIS in ERP environments of Vietnamese garment companies from managers' viewpoint.

\section{Conclusions and future research}

Focusing on the evaluation of integrated AIS in an ERP environment from the managers' viewpoint, this paper proposes a research model based on the BSC theory. The author (1) examine the status of assessing the effectiveness of integrated AIS in the ERP environment in Vietnamese garment companies and (2) identify the factors that determine the 
effectiveness of AIS in the ERP environment in such companies from managers' view. The author studied to develop and test scales of four (04) BSC research constructs to determine the effectiveness of integrated AIS in ERP environments in Vietnamese garment companies.

The results of the study presented the evaluation status of the effectiveness of integrated ERP-AIS in Vietnamese garment companies. Furthermore, based on the BSC theory model with four research constructs, the author has published 28 significant factors for assessing the effectiveness of integrated AIS in the ERP environment in Vietnamese garment companies from managers' viewpoint (Figure 8). Hopefully, the initial results of this paper would become a reliable reference for future research in the field of integrated AIS in an ERP environment in Vietnam in the garment and other industries as well. In addition, more research must be done on the evaluation of integrated AIS's effectiveness from the perspective of other stakeholders including AIS academic researchers, ERP-AIS solution providers and so on.

\section{References}

Ballantine, J. A., Galliers, R. D., \& Stray, S. J. (1996). Information systems/technology evaluation practices: Evidence from UK organizations. Journal of Information Technology, 11(2), 129-141. doi:10.1177/026839629601100204

Bhagwat, R., \& Sharma, M. K. (2007). Performance measurement of supply chain management: A balanced scorecard approach. Journal of Computers and Industrial Engineering, 53(1), 43-62. doi:10.1016/j.cie.2007.04.001

Blundell, B., Sayers, H., \& Shanahan, Y. (2003). The adoption and use of the Balance Scorecard in New Zealand: A survey of the top 40 companies. Journal of Pacific Accounting Review, 15(1), 49-74. doi:10.1108/eb037971

Bryant, L., Jones, D. A., \& Widener, S. K. (2004). Managing value creation within the firm: An examination of multiple performance measures. Journal of Management Accounting Research, 16(1), 107-131. doi:10.2308/jmar.2004.16.1.107

Carr, N. G. (2003). IT doesn't matter. Harvard Business Review Journal, 81(5), 41-49.

Chanopas, A., Krairit, D., \& Khang, D. B. (2006). Managing information technology infrastructure: A new flexibility framework. Management Research News, 29(10), 632651. doi:10.1108/01409170610712335

Chen, L., \& Mohamed, S. (2008). Contribution of knowledge management activities to organizational business performance. Journal of Engineering, Design and Technology, 6(3), 269-285. doi:10.1108/17260530810918289

Chia, A., Goh, M., \& Hum, S.-H. (2009). Performance measurement in supply chain entities: Balanced scorecard perspective. Benchmarking: An International Journal, 16(5), 605620. doi:10.1108/14635770910987832

Chriyha, A., Beidouri, Z., \& Bouksour, O. (2012). Proposal of a performance model based on the Balance Scorecard for the Moroccan textile industry. The International Journal of Computer Science Issues, 9(5), 410-417.

Churchill, G. A., Jr. (1979). A paradigm for developing better measures of marketing constructs. Journal of Marketing Research, 16(1), 64-73. doi:10.2307/3150876 
Coyne, J. G., Coyne, E. M., \& Walker, K. B. (2017). Accountant and tech: A game changer? Strategic Finance Journal, 98(9), 40-47.

Dao, V. T. (2002). Organizing public accounting system under computerized condition (Doctoral dissertation). Vietnamese Financial Institution, Vietnam.

Dunn, S. C., Seaker, R. F., \& Waller, M. A. (1994). Latent variables in business logistics research: Scale development and validation. Journal of Business Logistics, 15(2), 145172.

Farbey, B., Land, F., \& Targett, D. (1992). Evaluating investments in IT. Journal of Information Technology, 7(2), 109-122. doi:10.1057/jit.1992.16

Felice, F., D., \& Petrillo, A. (2013). Key success for organizational innovation in the fashion industry. International Journal of Engineering Business Management, 5(1), 27-36. doi: $10.5772 / 56882$

Gimžauskienè, E., \& Klovienè, L. (2014). Development of accounting system according to an information technology. Review of Economic Studies and Research, 7(2), 59-74.

Greenspan, A. (2000). Technology innovation and its economic impact. A speech before the National Technology Forum, St. Louis, Missouri via teleconference. Retrieved October 3, 2018, from Federal Reserve Board of Governors, Washington, D.C. website: https://www.federalreserve.gov/boarddocs/speeches/2000/20000407.htm

Grembergen, W. V., \& Haes, S. D. (2005). Measuring and improving IT governance through the balanced scorecard. Information Systems Control Journal, 2(1), 1-8.

Grembergen, W. V., \& Haes, S. D. (2017). Introduction to IT governance and its mechanisms minitrack. Paper presented at Proceedings of the 50th Hawaii International Conference on System Sciences, USA.

Hackman, D., Gundergan, S. P., Wang, P., \& Daniel, K. (2006). A service perspective on modeling intentions of on-line purchasing. Journal of Services Marketing, 20(7), 459470. doi:10.1108/08876040610704892

Hair, J. F., Black, B., Babin, B., Anderson, R. E., \& Tatham, R. L. (2005). Multivariate data analysis (6th ed.). Upper Saddle River, NJ: Pearson Education.

Hitt, M. A. (1988). The measuring of organizational effectiveness: Multiple domains and constituencies. Management International Review, 28(2), 28-40. doi:10.2307/40227880

Hoque, Z., \& Wendy, J. (2000). Linking Balance Scorecard measures to size and market factors: Impact on organization performance. Journal of Management Accounting Research, 12(3), 1-17. doi:10.2308/jmar.2000.12.1.1

Huang, L. (2008). Strategic orientation and performance measurement model in Taiwan's travel agencies. Service Industries Journal, 28(10), 1357-1383. doi:10.1080/02642060802250179

Huang, S. M., Lee, C.-L., \& Kao, A.-C. (2006). Balancing performance measures for information security management: A balanced scorecard framework. Industrial Management and Data Systems Journal, 106(2), 242-255. doi:10.1108/02635570610649880 
Kaplan, R. S., \& Norton, D. P. (1992). The balanced scorecard - Measures that drive performance. Harvard Business Review, 70(1), 71-79. Retrieved October 15, 2018, from https://www.researchgate.net/publication/13177691_The_Balance_ScorecardMeasures_That_Drive_Performance

Lee, J., Kao, H.-A., \& Yang, S. (2014). Service Innovation and Smart Analytics for Industry 4.0 and Big Data Environment. The 6th CIRP Conference on Industrial Product-Service Systems, Procardia CIRP, 16, 3-8. doi:10.1016/j.procir.2014.02.001

Lin, C., \& Pervan, G. (2003). The practice of IS/IT benefits management in large Australian organizations. Information and Management Journal, 41(1), 13-24. doi:10.1016/S03787206(03)00002-8

Luftman, J., \& Brier, T. (1999). Achieving and sustaining business-IT alignment. California Management Review, 42(1), 109-122. doi:10.2307/41166021

MacKenzie, S. B., Podsakoff, P. M., \& Jarvis, C. B. (2005). The problem of measurement model misspecification in behavioral and organisational research and some recommended solutions. Journal of Applied Psychology, 90(4), 710-730. doi:10.1037/0021-9010.90.4.710

Maqbool, M. H. (2015). A consolidated model of putting BSC into action textile industry in Pakistan. Science and Technology Journal, 6(2), 14-22.

Nguyen, B. L. (2013). Identifying and controlling the accounting information quality in ERPapplied environment in Vietnamese enterprises (Unpublished doctoral dissertation). University of Economics Ho Chi Minh City, Vietnam.

Nguyen, D. H. (2011). Organizing accounting information systems under IT-applied conditions in Vietnamese import-export enterprises (Unpublished doctoral dissertation). National Economics University, Vietnam.

Nguyen, D. T. (2013). Giáo trình phương pháp nghiên cứu khoa hoc trong kinh doanh - Tập 2 [Research methodology in business textbook (2nd ed.)]. University of Economics Ho Chi Minh City: NXB Tài chính.

Nguyen, H. D. (2012). Improving accounting information systems for Vietnamese public universities (Unpublished doctoral dissertation). National Economics University, Vietnam.

Palvia, P. C., Perkins, J. A., \& Zeltmann, S. M. (1992). The PRISM system: A key to organizational effectiveness at Federal Express Corporation. MIS Quarterly, 16(3), 277 292. doi:10.2307/249529

Park, J. H., Lee, J. K., \& Yoo, J. S. (2005). A framework for designing the balanced supply chain scorecard. European Journal of Information Systems, 14(4), 335-346. doi:10.1057/palgrave.ejis.3000544

Petter, S., DeLone, W., \& McLean, E. R. (2012). The past, present, and future of "IS Success". Journal of the Association for Information Systems, 13(5), 341-362. doi:10.17705/1jais.00296

Santhanam, R., \& Hartono, E. (2003). Issues in linking information technology capability to firm performance. MIS Quarterly, 27(1), 125-153. doi:10.2307/30036521 
Seddon, P. B., Graeser, V., \& Willcocks, L. P. (2002). Measuring organizational IS effectiveness: An overview and update of senior management perspectives. Database for Advances in Information Systems Journal, 33(2), 11-28. doi:10.1145/513264.513270

Silk, J. (1998). Caring at a distance. Journal of Philosophy and Geography, 1(2), 165-182. doi:10.1080/1366879X.1998.11644226

Sohal, A. S., \& Ng, L. (1998). The role and impact of information technology in Australian business. Journal of Information Technology, 13(3), 201-217. doi:10.1080/026839698344846

Suanmali, S., Karabay, G., \& Kurumer, G. (2011). A study of business performance through Key Performance Indicators (KPIs) in Thai garment industry. Paper presented at the 5th International Congress on Logistics and SCM systems, Seoul, Korea, 2011.

Sundin, L., Hochwälder, J., \& Bildt, C. (2008). A scale for measuring specific job demands within the health care sector: Development and psychometric assessment. International Journal of Nursing Studies, 45(6), 914-923. doi:10.1016/j.ijnurstu.2007.03.006

Taipaleenmäki, J., \& Ikaheimo, S. (2013). On the convergence of management accounting and financial accounting - The role of information technology in accounting change. International Journal of Accounting Systems, 14(4), 321-348.

Tran, P. (2007). Solutions for improving the quality of accounting software usage in Vietnamese enterprises (Unpublished doctoral dissertation). University of Economics Ho Chi Minh City, Vietnam.

Velcu, O. (2007). Exploring the effects of ERP systems on organizational performance: Evidence from finnish companies. Industrial Management and Data Systems Journal, 107(9), 1316-1334. doi:10.1108/02635570710833983

VIRAC Vietnam. (2018). Báo cáo tiêu chuẩn ngành dệt may Việt Nam [Report on Vietnam's garment industry standards]. Retrieved October 15, 2018, from ttp://viracresearch.com/industry/bao-cao-tieu-chuan-nganh-det-may-viet-nam-q22018. 